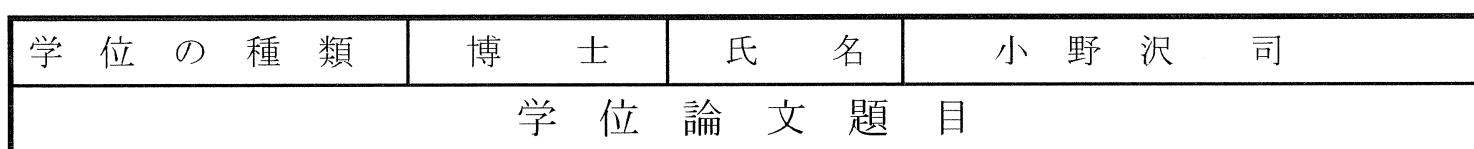

\title{
Nitric Oxide Induced Ectopic Firing in a Lumbar Nerve Root
}

With Cauda Equina Compression

(馬尾神経圧迫条件下において一酸化窒素に誘発される

神経根由来の異所性発火に関する研究)

$$
\text { 共著者名 }
$$

熱田 裕司、佐藤 雅規、猪川 輪哉

恒川博己、辛風

印刷公表の方法及び時期

\section{CLINICAL ORTHOPAEDICS AND RELATED RESEARCH}

Number 408, pp 167-173 March 2003

\author{
研究目的
}

腰椎椎間板ヘルニアの臨床症状として最も問題となるのは、坐骨神経痛と称される神経根 性疼痛である。坐骨神経痛の発生源として障害神経根の知覚線維に発生する異常興奮、寸な わち異所性発火が重要な役割を果たすと考えられる。ヘルニア塊が神経根を刺激して異所性 発火を誘発する機序としては、MRI などの画像検查で同定されるように、神経根が物理的圧 迫を受けることが挙げられる。しかし最近の臨床的研究から、ヘルニア塊の大きさや神経根 に対寸る圧迫の度合いと坐骨神経痛の程度は必ずしも相関しないことが判明してきた。この 事実から、坐骨神経痛を引き起こす機序として圧迫以外に、画像的には認識されない化学的 因子の関与が推定されるに至った。近年、ヘルニア塊と神経根が接触する局所に存在しうる 化学的因子の一つとして一酸化窒素 $(\mathrm{NO})$ が注目されている。そこで私は実際に NO が神経根 に異所性発火誘発寸る因子であるかどうかを確認寸るため実験を行った。ラットにおいて腰 部神経根由来の異所性発火を観察する手法を確立し、NO の存在が異所性発火に及ぼす影響 を解析した。さらに神経根に慢性圧迫を加えたモデルを用いてNOの作用の変化を解析した。 


\section{材 料・方 法}

\section{1.実験動物モデル}

24 匹の Wistar 系ラット（雄、体重 280～320g）を用いて実験を行った。これらを 8 匹ずつ 以下の 3 群に分けた。

圧迫群（8 匹）: ハロセンにて吸入麻酔し、無菌的な手術操作によって第 3 腰椎硬膜外腔背側 に直径 $2 \mathrm{~mm}$ 、長さ $8 \mathrm{~mm}$ のシリコンチューブを挿入し、その後 1 週間飼育した。チューブは 脊柱管横断面積の約 70\%を古め、第 5 腰神経根を含む馬尾を圧迫することを予め確認した。

sham 群 $(8$ 匹) : シリコン挿入を行わず、それ以外は狭窄群と同様の処置を行って 1 週間飼 育した。

対照群（8匹）：何ら処置を加えず 1 週間飼育した。

\section{2. 異所性発火の解析}

八ロセン麻酔下に人工呼吸管理とし、脳幹部切断による除脳、さらに筋弛緩剂による非動 化を行った上で麻酔を停止して実験を行った。試薬の投与経路として、第 5 腰椎硬膜外腔に カテーテルを挿入した。続いて後肢を展開して腓腹神経を露出し切断した。腓腹神経中枢側 遠位端より、双極銀線電極を用いて神経活動を導出した。得られた神経活動は波形分析装置 に入力し、逆行性の異所性発火活動を抽出した。異所性発火活動はリアルタイムにスパイク 頻度ヒストグラムとして表示した。予備実験として、第 5 腰神経根に生ずる異所性発火が今 回の計測系で導出できることを確認した。設定した 3 群の動物について、まず安静時の初期 発火活動を記録した後、予め留置した硬膜外カテーテルから NO 供与体である sodium nitroprusside (SNP) $10 \mathrm{mM} 0.1 \mathrm{ml}$ を注入し、発火活動の变化を 10 分間観察した。各動物で得ら れた初期発火頻度、および NO により誘発された反応から最大増加頻度を求め、各群間の差 を検討した。統計処理にはStudent's T 検定を用いた。

\section{結果}

全ての動物において、腓腹神経から安定した自発発火活動が導出された。記録上のスパイ ク振幅は 5〜 $20 \mu \mathrm{V}$ で、各記録には一般に複数の振幅のスパイクが含まれていた。この腓腹 神経の初期発火活動頻度（スパイク/秒）は、圧迫群で 20～360、平均 147.1、sham 群で 25〜 125、平均 52.4、対照群で 12〜80、平均 52.6 であった。圧迫群は、sham 群、対照群と比べ統 計的に有意に高值であった。また sham 群と対照群間には有意差を認めなかった。

SNP 投与後、圧迫群では 8 匹全例で速やかな発火増強が顕著にみられ、投与後 2 から 3 分 で発火頻度は最大值を示した。sham 群では 4 匹に軽度の反応を認めた。対照群では 3 匹にわ ずかな反応を記録したのみであった。SNP 投与後の最大増加頻度（スパイク秒）は、圧迫群 で 80〜 582、平均 300.1、sham 群で 0〜225、平均 64.7、対照群は 0〜30、平均 10.3 であった。 
圧迫群の発火頻度増加は、sham 群、対照群と比べ有意に高值を示した。また sham 群と対照 群間には有意差を認めなかった。圧迫群において SNP による異所性発火増加の持続時間は、 60〜360 秒、平均 205.0 秒であった。SNPによる発火増加終了時には、いずれの場合もほぼ 初期発火頻度の值に戻った。一部の圧迫群ラットに複数回 SNP 投与老行うと、発火頻度増大 の反応には再現性が認められた。

$$
\text { 考案 }
$$

神経根障害が存在すると疼痛を主体とする自発性の異常感覚が生ずる。これは神経生理学 的には神経根における過剩な興奮発生、すなわち異所性発火が中枢に伝達されるためと理解 される。本研究で導出に用いた腓腹神経は知覚神経であり、解剖学的には第 5 腰神経根に所 属する。神経根レベルで発生した異所性発火は中枢方向と同時に末梢側に向かって逆行性に 伝導するため、腓腹神経から得られた逆行性の神経活動を解析寸ることにより第 5 腰神経根 に発生した異所性発火の動態を解明寸ることが可能となる。本研究の予備実験でも、第 5 腰 神経根に機械的刺激を加えると、逆行性に伝搬した異所性発火活動の変化を腓腹神経から実 際に導出できることを確認している。また異所性発火の主たる発生部位局在については、過 去のいくつかの研究から後根神経節と推定される。

腰椎椎間板へルニアによる坐骨神経痛の発症過程においては物理的圧迫と化学的因子が複 合的に関与寸ることが近年示唆されている。しかし、それらの二つの要素のそれぞれによっ て、また両要素が加重する条件でいかなる作用を及ぼすかについて異所性発火の観点から客 観的解析した研究はこれまでに存在しない。本研究では、第 3 腰椎シリコンチューブを挿入 した動物モデルを用いたが、これは解析対象となる第 5 腰神経根に対して馬尾レベルで慢性 的な物理的圧迫を加える設定である。その結果、異所性発火頻度は圧迫の無い動物と比べて 有意に増加した。このことは、一次求心性線維の一部に物理的圧迫を受けた場合に、ある時 間経過を経て後根神経節細胞の興奮性が増大したことを示している。

化学的因子として注目される NO は脱出へルニア塊より産生されること、ヘルニア周囲の 肉芽組織に NO 産生細胞が観察されること、後根神経節内に NO 合成酔素が存在することな どが報告され、椎間板へルニアの病態において神経根が NO に暴露される可能性は高い。今 回の実験では神経根周囲に直接 NO 供与体を投与寸る手法を用いてその作用を評価した。NO の作用として、sham 群や対照群では反応性の異所性発火増大がほとんど生じないのに対し て、圧迫群では著明な発火增大を惹起した。この結果は、神経根の慢性圧迫により後根神経 節細胞の機能的変化や防御機構の破綻が生じ、外的環境に存在する NO に対して化学感受性 が立進したものと推測される。すなわち、NO は健常神経根に対する影響は少ないが、慢性 障害神経根に対しては疼痛増強因子となりうることを示唆した。今回観察された神経根の感 受性変化は、他の化学的因子についても生ずる可能性があり、椎間板へルニアの病態におい て重要な役割を果たしていると推察された。 
結 論

本研究の結果以下の知見が得られた。

1．神経根障害の病態を異所性発火から解析できる実験モデルを確立した。

2. 神経根の慢性圧迫は、異所性発火増大を誘発した。

3. NO は健常神経根に対寸る影響は少ないが、圧迫障害神経根の異所性発火を著明に増大さ せた。

\section{引用 文 献}

1. Wall PD, Devor M.

Sensory afferent impulses originate from dorsal root ganglia as well as from the periphery in normal and nerve injured rats.

Pain 17: 321-39, 1983

2. Ozawa K, Atsuta $\mathrm{Y}$, Katoh T:

Chronic effects of the nucleus pulposus applied to nerve roots on ectopic firing and conduction velocity.

Spine 26: 2661-2665, 2001.

3. Hashizume $\mathrm{H}$, Kawakami M, Nishi $\mathrm{H}$, et al

Histochemical demonstration of nitric oxide in herniated lumbar discs. A clinical and animal model study.

Spine 22:1080-1084,

$$
\text { 参考 論 文 }
$$

1. 小野沢 司、加茂 裕樹、宮津 誠、保田 雅憲、前田 龍智、辻 宗 啓 胸腰椎損傷の治療経験

北海道整形外科外傷研究会誌 第 13 巻 P94-98, 1997

2. 小野沢司、武田 直樹、熱田 裕司、竹光 義治、原田吉雄

Dystrophic type $の$ neurofibromatosis に伴う春柱変形の手術成績

-術後 10 年以上経過例について-

脊柱変形 第 14 巻第 1 号 P175-180, 1999 
3. 小野沢 司、加茂 裕樹、平山 隆三、宮津 誠、保田 雅憲、後山 恒範 中下位頚椎脱臼骨折の治療経験 -固定方法についての検討-

別冊整形外科 No.37, p208-211, 2000

4. 小野沢 司、加茂 裕樹

オライオンプレート、ハイドロキシアパタイトスペーサーを併用した

頝椎前方固定の試み

脊椎・脊䯣手術手技 Vol. 2, No. 1, P37-40, 2000

5. 小野沢 司、熱田 裕司、武田 直樹、竹光 正和、小林 徹也、松野 丈夫 実験的脊柱管狭窄による腰部神経根の NO 感受性変化

-ラット in vivo モデルの異所性発火を指標とした検討-

臨床整形外科 第 36 巻 4 号 P535-539, 2001 
学位論文の審查結果の要旨

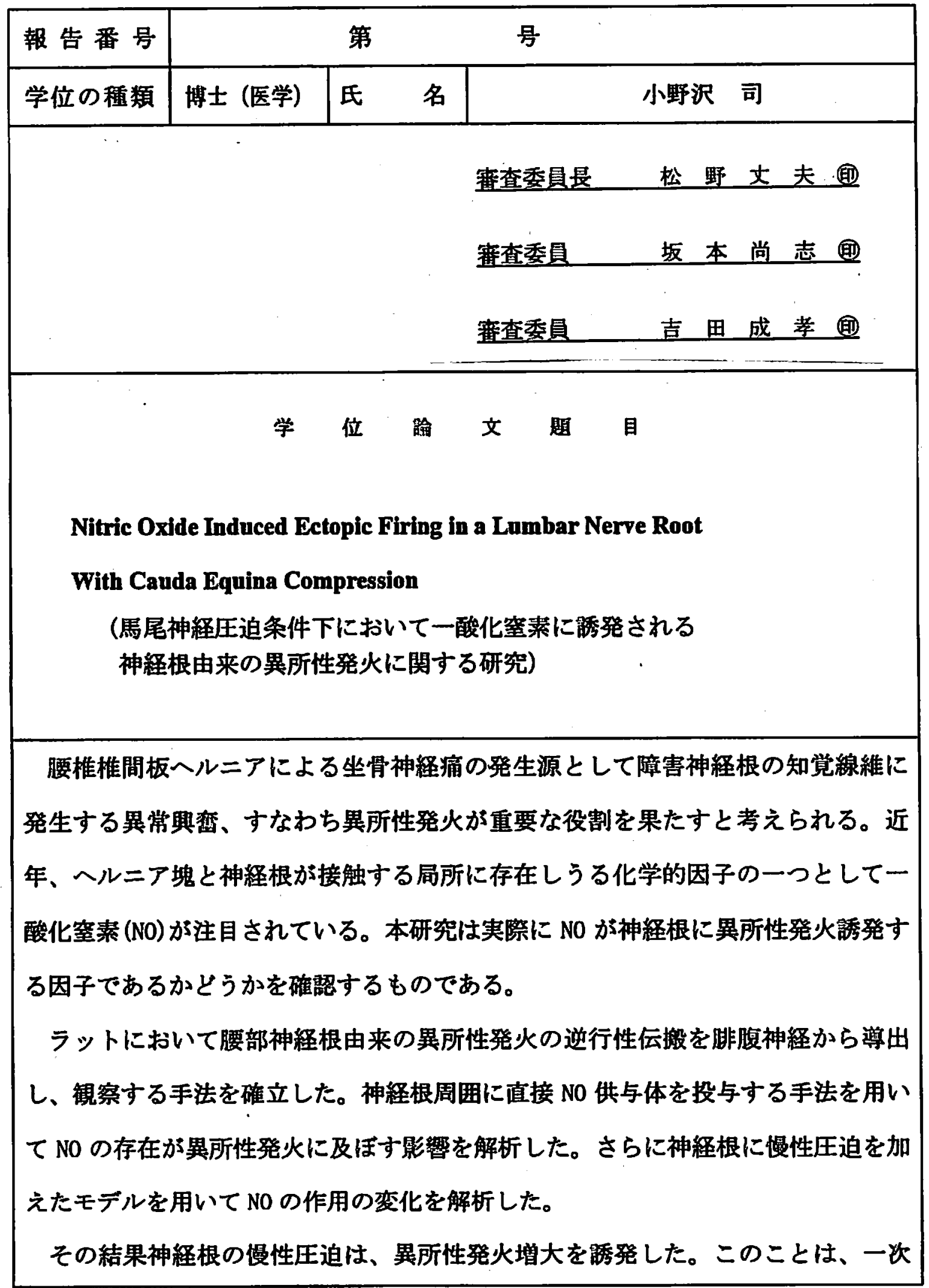


求心性線維の一部に物理的圧迫を受けた場合に、ある時間経過を絓て後根神経節 細胞の興蛮性が增大したことを示している。さらに、NO は健常神経根に対する影 製は少ないが、圧迫障害神経根の異所性発火を著明に增大させた。このことは、NO は慢性障害神経根に対しては疼痛増強因子となりうることを示唆した。

今回観察された神経根の感受性変化は、他の化学的因子についても生ずる可能 性があり、椎間板ヘルニアの病隹において重要な役割を果たしていると推察され た。今回の実験モデルを用いることにより、異所性発火を指摽として、神経根障 害の病隹の研究、さらには神経根障害に対する治療薬の効果を定量的に解析でき る可能性がある。

本論文は腰椎椎間板ヘルニアにおける神経根、後根神経節に対する機械的圧迫 や化学的因子の影響を異所性発火の観点から解明した重要な論文で、この分野の 研究の発展に大きく霉与するものと考えられる。

なお、各富査委員より、本踚文とその関連領域に関して試問が行われた結果、適 切な回答が得られた。以上より、本蓸查委員会は本論女を学位論文に值するもの と判定した。 